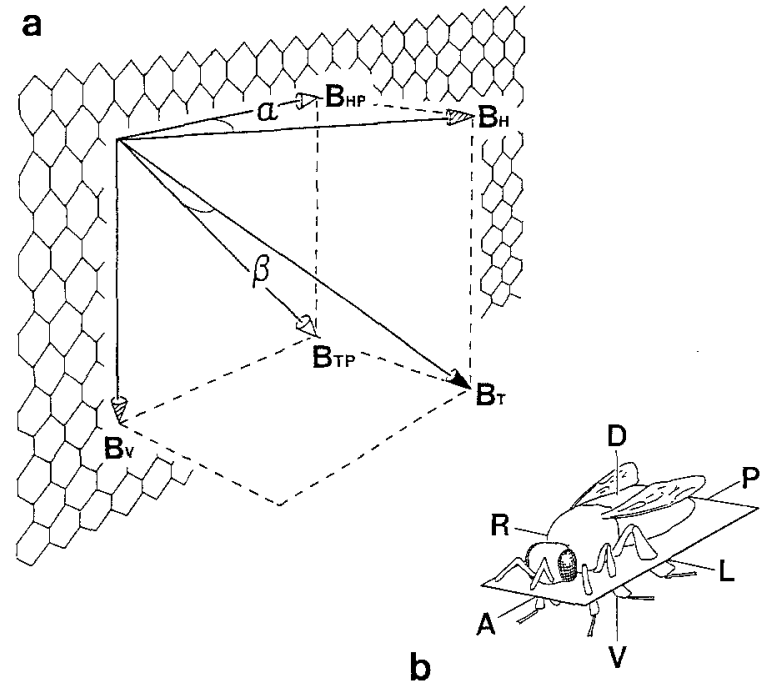

Fig. 2. a) Illustration of the relationship of the magnetic elements of the earth's field with a honeycomb oriented at some arbitrary angle $\alpha$ to the field (cf. b). Vectors BTP and BHP are components of the total vector, BT, and its horizontal component, BH, BTP and BHP lie in the plane of the comb. The vertical component, $\mathrm{Bv}$, already lies in the plane of the comb. BT and BH make angles $\beta$ and $\alpha$, respectively, with the plane of the comb. The frontal plane of the bee (b) coincides with the plane of the comb when the bee is dancing or following a dance. If a bee were using a dip compass referenced to the plane of the comb (there are no other likely references), it would have to detect the direction of BTP to account for the disappearance of the Mißweisung in the directions of BTP. However, the angle $\beta$ is in no way special and therefore does not permit detection based on dip. The angle $\alpha$ is the largest angle that the magnetic field makes with the comb, and Bvobviously makes the smallest angle $\left(0^{\circ}\right)$ with the comb. See text for a discussion of receptor mechanisms consistent with these facts and observed behaviors

ways make an angle of $0^{\circ}$ with the comb. There are a multitude of possible compass mechanisms: three candidates for magnetoreceptors are consistent with the above discussion. The first receptor model is a directional compass that samples in at least two planes: the dorsoventral and the frontal planes. A "spherical" compass that sampled in three mutually perpendicular planes or more would suffice and could be an axial compass. The second possibility for a compass mechanism is a polar, frontal, directional compass. Two experimental treatments involving the exposure of bees to reversal of the vertical component of the earth's magnetic field (horizontal polarity remaining the same) and reversal of both the horizontal and vertical components (dip angle remaining the same) will categorically resolve the question of whether the bee's compass is polar or axial. The third receptor model is an intensitydetecting receptor which could be restricted to sampling in the bee's frontal plane or along a single body axis. Unpublished results show that bees do detect gradients in magnetic fields. This supports a compass model that responds to intensity as well as direction.

Received September 7, 1992

1. Blakemore, R. P.: Science 190, 377 (1975)

2. Lindauer, M., Martin, H.: Z. vergl. Physiol. 60, 219 (1968)

3. Lindauer, M., Martin, H., in: Animal Orientation and Navigation, p. 559 (S.R. Galler et al., eds.). Washington, D. C. : NASA 1972

4. DeJong, D.: J. Comp. Physiol. 147, 495 (1982)

5. Walker, M. M., Bitterman, M. E.: J. Comp. Physiol. A 157, 67 (1985); J. Exp. Biol. 141, 447 (1989); 145, 489 (1989); Kirschvink, J. L., Kobayashi Kirschvink, A.: Am. Zool. 31, 169 (1991)

6. Lindauer, M.: Proc. XV Int. Congr. Entomol., p. 450 (1977)

7. Batschelet, E.: Circular Statistics in Biology. London: Academic Press 1981

8. [7], p. 61

9. Wiltschko, W., Wiltschko, R.: Science 176, 62 (1972); Kiepenheuer, J.: Behav. Ecol. Sociobiol. 14, 81 (1984)
Naturwissenschaften 80, 43-46 (1993) cSpringer-Verlag 1993

\section{Electric Signaling and Impedance Matching in a Variable Environment}

\section{The Electric Organ of Mormyrid Fish Actively Adapts to Changes in Water Conductivity}

\section{B. Kramer and B. Kuhn}

Zoologisches Institut der Universität, W-8400 Regensburg, FRG

The electric organs of elephant nose fish, the Mormyridae, are adaptations for active electrolocation ([1]; recent review, [2]) and electrocommunication (reviews, [3-5]). As in any battery, the current and voltage that the electric organ generates depend on the resistance of the load $[6,7]$. The comparison of marine and freshwater strongly electric fish revealed anatomical and physiological adaptations matching the electric organ to the great difference in impedance between the two environments [6].

Weakly electric fish live in tropical freshwaters of low and seasonally variable conductivity (about 5-150 $\mu \mathrm{S} / \mathrm{cm}$, or a resistivity of 200 to $7 \mathrm{k \Omega} \cdot \mathrm{cm}$ ). It is unknown whether weakly electric fish are able to adapt the biophysical properties of their electric organ to this great impedance variation. The inability to do so would greatly affect the EOD (electric organ discharge) waveform, as shown in the mormyrids Pollimyrus isidori and $\mathrm{Pe}$ trocephalus bovei [8], and probably reduce the usefulness of the EOD as a 
communication and orientation signal. The present paper investigates the short- and long-term effects of a change in water conductivity on the output of the electric organ of two closely related Campylomormyrus species with similar EOD waveforms.

The mormyrid discharge is neurally evoked and usually consists of two main phases, as also observed in both Campylomormyrus species investigated in the present paper (Fig. $1 \mathrm{~A} \star, D \star$ ). The second (N) phase is electrically triggered by the first, the $\mathrm{P}$ phase (review [6]). While the voltage of the first, neurally evoked, phase increases linearly (similar to a battery) when water resistance is increased, for the second, electrically evoked, $\mathrm{N}$ phase this is true only up to a certain threshold in water resistance, beyond which the $\mathrm{N}$ phase decreases in amplitude and increases in duration [7]. At still higher water resistances, though occurring naturally, the second phase is greatly reduced and the EOD waveform severely distorted [7, 8].

Although mormyrids appear to rely primarily on the sequence of EOD time intervals for intraspecific communica- tion $([9,10]$; review, [5]; see also [11]), in addition, they might discriminate the often subtle differences in speciesspecific EOD waveform [12, 13], such as those presented here (Fig. $1 \mathrm{~A} \star$, $\mathrm{D} \star$ ), and also individual differences that are sometimes present $([8,14]$; review in [15]). Conditioned discrimination of artificially generated natural EOD waveforms recorded from different individuals was shown in $\mathrm{Pol}$ limyrus isidori for the first time [16]. However, the recognition of conspecifics and mates on the basis of EOD waveform cues seemed difficult,
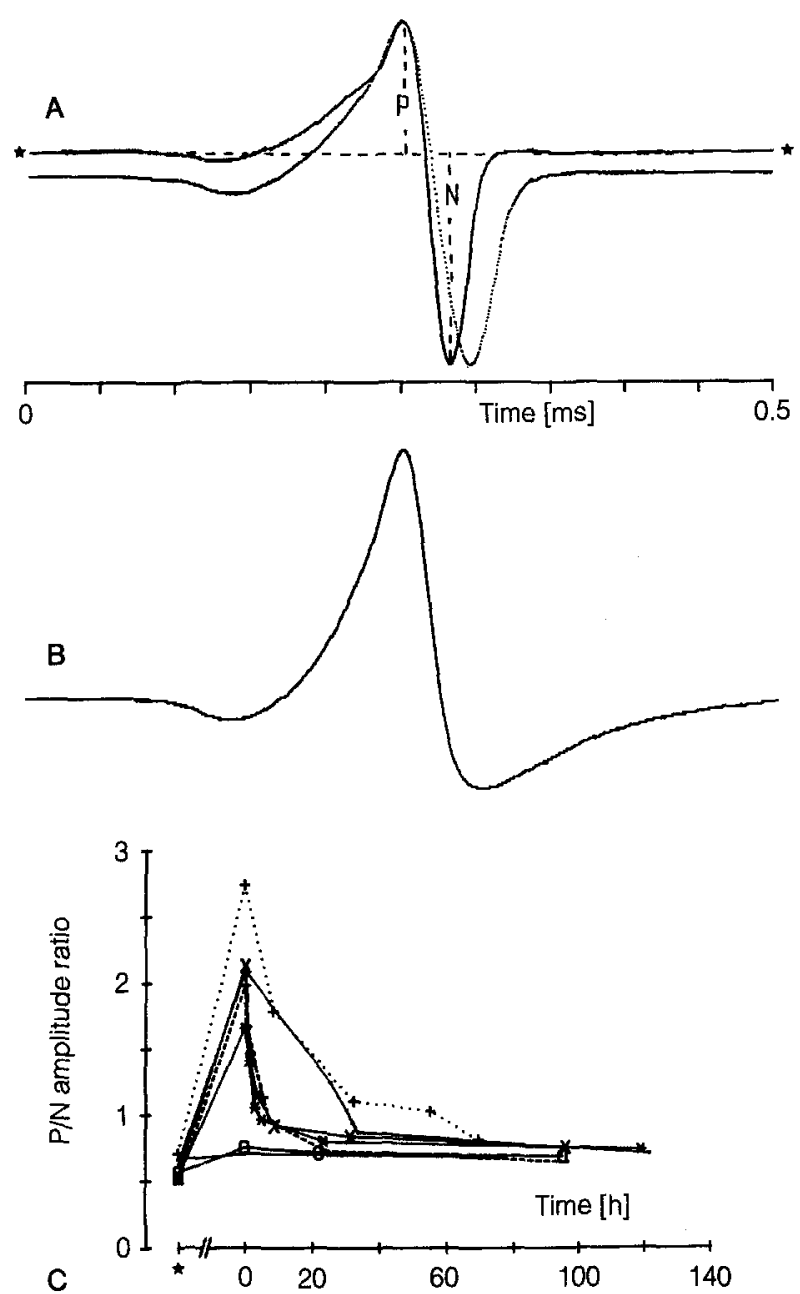
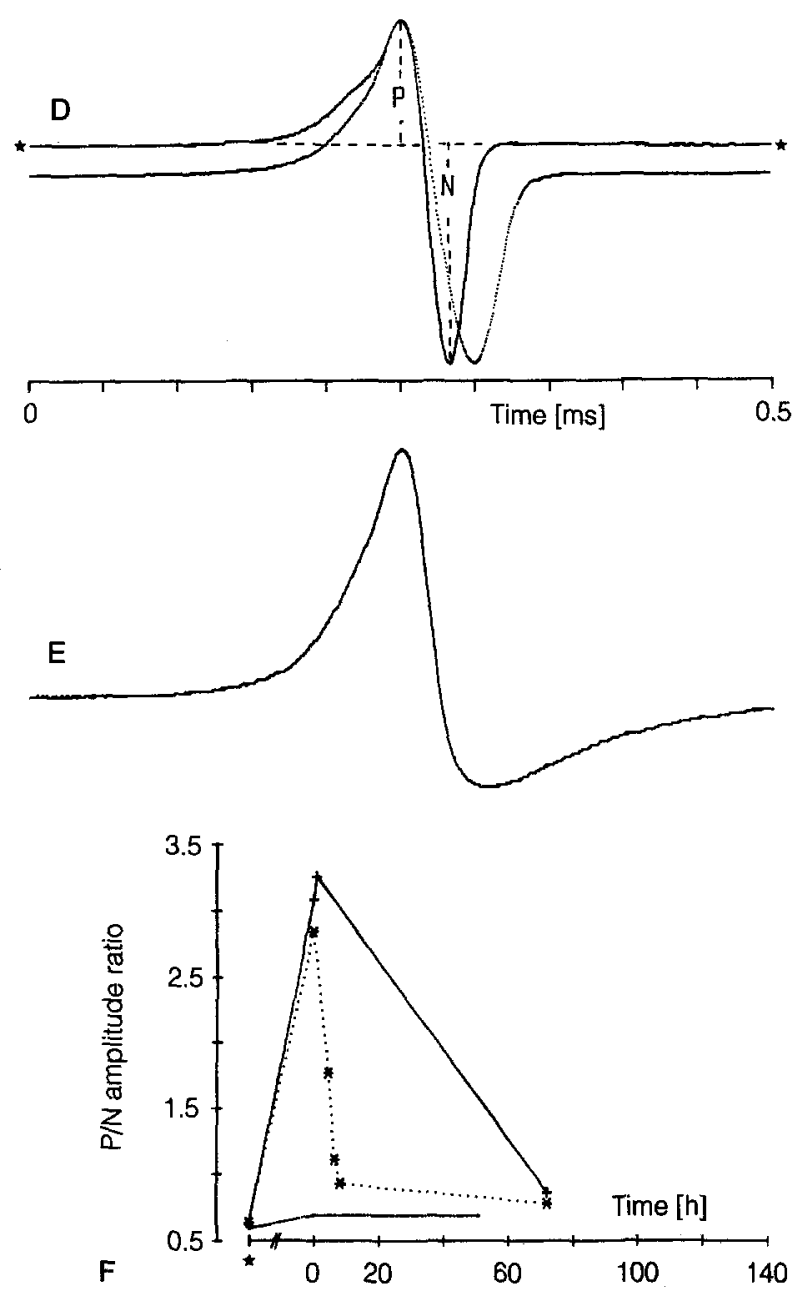

Fig. 1. Short- and long-term effects of water of low conductivity on the electric organ discharge (EOD) of Campylomormyrus tamandua (A-C) and C. rhynchophorus (D-F). All EODs are represented as voltage over time (ms), digitized at $2 \mathrm{MHz}$. A, D) EODs of both species have a $\mathrm{P}$ - and an $\mathrm{N}$-phase, measured from baseline, as indicated for the EODs recorded in water of high conductivity before the test $(135 \mu \mathrm{S} / \mathrm{cm}$; line between asterisks). Superimposed are the EODs of the same fish observed after $70 \mathrm{~h}$ of exposure to water of low conductivity, normalized to the same peak-to-peak amplitude $[10 \mu \mathrm{S} / \mathrm{cm}$; points merging into (lower) baselines due to the high digitization rate]. Note the relatively lower N-phase amplitude in both species in water of low conductivity. B, E) EODs of both species immediately after the transfer of fish from water of high to water of low conductivity, showing an N-phase greatly reduced in amplitude but of longer duration. C, F) Time course of the P/N amplitude ratio before $(\star)$ and after transfer of fish from water of high to water of low conductivity. Time zero $=$ immediately after transfer of fish (measurement within $1 \mathrm{~min}$ ). Different curves for individual fish $(n=7$ in $\mathrm{C} ; n=3$ in $\mathrm{F}$ ). Note that on exposure to water of low conductivity, there is an immediate, steep increase in the P/N ratio in most fish, followed by a slow decline to almost „normal." values within $20-80 \mathrm{~h}$. This is evidence for an active impedance matching process in the electric organ 
if not impossible, when EOD waveforms are severely distorted by any change in water conductivity [8]. We now report on the remarkable ability of the Campylomormyrus electric organ to adapt to a drastically changed water conductivity within 2 days, so that the EOD waveform typical of the species is largely restored.

The EODs of both Campylomormyrus species investigated, $C$. tamandua $(n=$ 7; standard length 9-14 cm) and $C$. rhynchophorus ( $n=3$; SL 9-10 cm), which are mainly found in central Africa, are similar in waveform and duration (biphasic pulses of about $140 \mu \mathrm{s}$ duration; in $C$. tamandua there is an additional pre-potential of weak amplitude; Fig. $1 \mathrm{~A} \star, \mathrm{D} \star$ ). All fish were caught near Kinshasa (according to the commercial importer). The response of the EOD waveform of both species to a sudden change in water conductivity was studied.

Fish were kept at $250 \pm 5 \mu \mathrm{S} / \mathrm{cm}$ for at least 2 weeks prior to the experiments at $27 \pm 1^{\circ} \mathrm{C}$ in $45-1$ tanks (12:12 L:D cycle). EODs were recorded in a $120-1$ tank, with a single fish centered between a pair of low impedance carbon electrodes $28 \mathrm{~cm}$ apart, one in front of its head and the other behind its tail. The output of a wide-band preamplifier (1-100000 Hz; variable gain $10 \times-100 \times$ ) was fed directly into an $\mathrm{A} / \mathrm{D}$ converter with memory and pretrigger circuit ( 8 bit vertical resolution, $2 \mathrm{MHz}$ sampling rate; 2000 memory locations); the data samples were stored and analyzed by computer.

On transferring these fish to water of very low conductivity $(10 \pm 2 \mu \mathrm{S} / \mathrm{cm})$ the N-phase duration of the EOD greatly increased (especially in five out of seven $C$. tamandua, and two out of the three $C$. rhynchophorus ), while the P-phase duration was very little affected for all fish (the $\mathrm{P}$ - and the N-phase durations were measured from baseline; Fig. 1B, E; Table 1).

Most fish showed a dramatically altered EOD waveform: relative to the P-phase, the amplitude of the N-phase was reduced to $43.1 \pm \mathrm{SE} 10 \%$ of its original value in C. tamandua $(n=7)$, and to $42.7 \%$ in $C$. rhynchophorus ( $n=3$; mean values). Only three of these fish managed to produce an EOD waveform more or less typical of the species even under conditions of such low conductivity, with $\mathrm{N}$-phase ampli-

Table 1. EOD waveform changes after the transfer of fish from water of high conductivity $(250 \mu \mathrm{S} / \mathrm{cm})$ to water of low conductivity $(10 \mu \mathrm{S} / \mathrm{cm})$; immediately after the transfer, shown in regular type, and at least $70 \mathrm{~h}$ later (after adaptation, in italics) (\% of original value, mean \pm standard error)

\begin{tabular}{lll}
\hline & $\begin{array}{l}\text { C. tamandua } \\
(n=7)\end{array}$ & $\begin{array}{l}\text { C. rhynchophorus } \\
(n=3)\end{array}$ \\
\hline N-phase duration & $482.9 \pm 83.7$ & 316 \\
N-phase amplitude & $135.5 \pm 7.63$ & 133.8 \\
& $43.1 \pm 9.99$ & 42.7 \\
N-phase area & $82.5 \pm 3.1$ & 80.2 \\
& $155.1 \pm 6.54$ & 130.5 \\
& $120.6 \pm 5.77$ & 109.1 \\
\hline
\end{tabular}

tudes between 74 and $94 \%$ of the original values. The increase in the $\mathrm{N}$-phase duration was on the average 4.8 -fold in C. tamandua $(n=7)$, and 3.2-fold in C. rhynchophorus $(n=3)$.

The increase in duration greatly outweighed the loss in amplitude: relative to the P-phase, the area of the N-phase increased to an average 155.1 $\pm \mathrm{SE}$ $6.54 \%(n=7)$ of its original value in C. tamandua, and $130.5 \%$ in the three C. rhynchophorus (Table 1).

These immediately observed effects were followed by a slow recovery of the $\mathrm{N}$-phase within about $30-48 \mathrm{~h}$, in spite of the very low conductivity of the water $(10 \mu \mathrm{S} / \mathrm{cm})$, as measured by the ratio of $\mathrm{P} / \mathrm{N}$ amplitudes (Fig. 1 C, F). Although for a human observer the species-specific EOD waveforms reappeared in all fish, the recovery was incomplete even after 3-7 days (when further change became so slow it could no longer be detected), as the N-phase amplitudes rose to only $82.5 \pm \mathrm{SE}$ $3.1 \%$ in C. tamandua $(n=7)$, and to a mean $80.2 \%$ in C. rhynchophorus ( $n$ $=3$ ), of the original values observed in water of high conductivity (Fig. 1A, D; EODs without $\star$ ). Even after 3 months in water of $10 \mu \mathrm{S} / \mathrm{cm}$, the $\mathrm{N}$ amplitude of one C. tamandua, which was used to detect possible long-term effects, had risen to only $86 \%$ of the original value.

Although greatly shortened, the $\mathrm{N}$-phase durations did not recede to the original values, remaining at $135.5 \pm$

$\mathrm{SE} 7.6 \%$ for $C$. tamandua $(n=7)$ and a mean $133.8 \%$ for $C$. rhynchophorus ( $n=3$ ), compared to the original values. The area of the N-phase decreased to a mean $120.6 \pm \mathrm{SE} 5.8 \%$ in C. tamandua $(n=7)$ and $109.1 \%$ in $C$. rhynchophorus $(n=3)$, thus also re- maining above the original values (Table 1).

Opposite effects were observed when fish, after adapting to water of low conductivity $(10 \pm 2 \mu \mathrm{S} / \mathrm{cm})$ for 14 days, were transferred back into water of relatively high conductivity ( $150 \pm$ $5 \mu \mathrm{S} / \mathrm{cm})$ : as an immediate effect, the $\mathrm{N}$-phase increased in amplitude and decreased in duration. Both effects waned after 2-3 days of exposure to water of high conductivity, but a stable difference from the observations made at $10 \mu \mathrm{S} / \mathrm{cm}$ remained. For example, immediately after the transfer of the fish to water of high conductivity the amplitude of the $\mathrm{N}$-phase relative to the $\mathrm{P}$-phase rose, on the average, to $146.9 \%$ of the value observed at 10 $\mu \mathrm{S} / \mathrm{cm}$ (between 136 and $154.8 \%$ ); this difference decreased to a stable mean of $127.2 \%$ after 5 days (119-134\%; two $C$. tamandua and one $C$. rhynchophorus studied). Permanent effects of the EOD waveform, graded according to water conductivity, were especially prominent at water conductivities below $70 \mu \mathrm{S} / \mathrm{cm}$ (six $C$. tamandua and three $C$. rhynchophorus studied).

These results show that the Campylomormyrus electric organ can actively adapt to water with a wide range of conductivities, ensuring a degree of independence from environmental constraints. Although the signal constancy (after adaptation) as shown here is far from perfect, it may be sufficient for the requirements of active electrolocation, electrocommunication, and species recognition.

The physiological mechanisms of active impedance matching of the mormyrid electric organ, as shown here, are unknown. They probably include the osmotic stress encountered when the 
water conductivity suddenly decreases, thus initiating a hormonally mediated, biochemical response chain [17]. This could lead to an increased synthesis of the channel proteins of the electrocyte cell membrane, strengthening the electric organ as a voltage and current source under conditions of low conductivity.

An adaptation to water of high conductivity may be quite different from adaptation to water of low conductivity, since increasing a water conductivity that is as low as $10 \mu \mathrm{S} / \mathrm{cm}$ can hardly be regarded as stressful. Also, the membrane surface of the electrocytes composing the electric organ could change with water conductivity (as shown for androgenic hormones: $[18,19])$. The alternative hypothesis of impedance matching by the addition or reduction of electrocytes or columns of electrocytes seems highly unlikely, given the rather stable number of electrocytes per column, and the crammed position of the electric organ in the caudal peduncle of the fish [20].
Supported by the Deutsche Forschungsgemeinschaft (Sonderforschungsbereich 4, Teilprojekt H 1).

Received July 13 and September 28, 1992

1. Lissmann, H. W.: J. Exp. Biol. 35, 156 (1958)

2. Bastian, J., in: Electroreception, p. 577 (T. H. Bullock, W. Heiligenberg, eds.). New York: Wiley 1986

3. Moller, P.: Trends Neurosci. 3, 105 (1980)

4. Hopkins, C. D., in: Electroreception, p. 527 (T. H. Bullock, W. Heiligenberg, eds.). New York: Wiley 1986

5. Kramer, B.: Electrocommunication in teleost fishes: Behavior and experiments. Berlin: Springer 1990

6. Bennett, M. V. L., in: Fish physiology, Vol. V, p. 347 (W. S. Hoar, D. J. Randall, eds.). London-New York: Academic Press 1971

7. Bell, C. C., Bradbury, J., Russell, C. J.: J. Comp. Physiol. 110, 65 (1976)
8. Bratton, B. O., Kramer, B.: Exp. Biol. 47, 227 (1988)

9. Moller, P., Bauer, R.: Anim. Behav. 21, 501 (1973)

10. Kramer, B.: Behav. Ecol. Sociobiol. 6, 67 (1979)

11. Crawford, J. D.: Brain Behav. Evol. 38, 20 (1991)

12. Hopkins, C. D.: Am. Zool. 21, 211 (1981)

13. Kramer, B.: Behav. Ecol. Sociobiol. 4, $61(1978)$

14. Hopkins, C. D., Bass, A. H.: Science 212, 85 (1981)

15. Landsman, R. E., Harding, C. F., Moller, P., Thomas, P.: Horm. Behav. 24, $532(1990)$

16. Graff, C., Kramer, B.: Ethology 90, 279 (1992)

17. Mazeaud, M. M., Mazeaud, F., in: Stress and fish, p. 49 (A. D. Pickering, ed.). New York: Academic Press 1981

18. Bass, A. H., Denizot, J. P., Marchaterre, M. A.: J. Comp. Neurol. 254, 511 (1986)

19. Bass, A. H., Hopkins, C. D.: J. Comp. Physiol. A 156, 587 (1985)

20. Bruns, V.: Z. Zellforsch. 122, 538 (1971)

\section{BUCAUBESPRECHUNGEN}

Chemische Ökotoxikologie. Von $H$. Parlar und D. Angerhöfer. BerlinHeidelberg-New York: Springer 1991. 384 S., 194 Abb., DM 48,--

Die Ökotoxikologie ist ein relativ junges interdisziplinäres Fachgebiet, das als Aufgabe die Aufklärung der natürlichen und anthropogenen Einflüsse auf das Vorkommen und das Verhalten von Chemikalien, die Erforschung ihrer Wirkung auf Arten und natürliche Systeme sowie die Entwicklung von Analysen- und Testmethoden zur Untersuchung der Kontamination einzelner Umweltbereiche und von Konzepten zur Bewertung des Gefahrenpotentials von Chemikalien hat. Der Schwerpunkt liegt dabei auf der Betrachtung natürlicher Systeme als Ganzes. Dafür werden Verfahren aus sehr unterschiedlichen Bereichen wie der Chemie, Biologie, Medizin, Meteorologie, Bodenkunde und Ökonomie herangezogen.

Auf der Basis dieser Aufgabenbeschreibung ist das Springer-Lehrbuch „Che- mische Ökotoxikologie“ erschienen. Es versucht laut Vorwort, einem interdisziplinären Leserkreis die wissenschaftlichen Strategien und Konzepte der ökotoxikologischen Bewertung von Chemikalien nahezubringen. Trotz der Komplexität der chemischen Ökotoxikologie ist den Autoren ihr Vorhaben gut gelungen.

Das Lehrbuch ist in fünf größere $\mathrm{Ab}$ schnitte unterteilt. Im ersten Teil, der die Abschnitte 1 bis 3 umfaßt, werden das Verhalten von Chemikalien in der Umwelt, die Einflüsse darauf und die Wirkungen auf Organismen bzw. ökologische Systeme beschrieben. AnschlieBend werden im vierten Abschnitt Methoden präsentiert, mit denen das Verhalten von Chemikalien in der Umwelt untersucht werden kann. Der fünfte Abschnitt ist den Möglichkeiten zur Abschätzung der potentiellen Gefährlichkeit von Chemikalien gewidmet.

Das Buch ist die ausgearbeitete Niederschrift einer Vorlesungsreihe, die unter dem Titel „Einführung in die chemische Ökotoxikologie" seit dem Jahr 1987 an der Gesamthochschule Kassel als Pflichtfach für Studenten der Chemie und als Wahlpflichtfach für Studenten der Biologie und der Umweltsicherung gehalten wird. Aus diesem Grund stellt es nicht die Ökotoxikologie vollständig dar, sondern beschränkt sich auf die chemischen Aspekte, wobei aber die Vorgehensweise in diesem interdisziplinären Gebiet, das sich in den letzten 20 Jahren so richtig entwickelt hat, deutlich wird.

Allen an der chemischen Umweltforschung Interessierten kann dieses Lehrbuch, das verständlich und klar geschrieben ist, empfohlen werden. Es setzt allerdings ein chemisches Grundwissen voraus, das in manchen Bereichen schon recht fundiert sein muß.

M. Mayer (Freiburg)

Spuren der Menschwerdung. Die Evolution des Homo Sapiens. Von R. Lewin. 